\title{
The Countermeasures and Problems of the British and American Literature Teaching in Colleges
}

\author{
Zhongmeng Chen ${ }^{1, a}$, Hongxia Dai ${ }^{2, b}$ \\ ${ }^{1}$ Foreign Languages School, Nanchang Normal University, Nanchang 330032, China; \\ ${ }^{2}$ School of National Education, Nanchang Institute of science \& Technology, Nanchang 330108 , \\ China; \\ accsuzju@163.com; 'bluochenpaper@163.com
}

Keywords: British and American Literature Teaching, Problems, Solutions.

\begin{abstract}
As an important part of the humanities, British and American Literature plays an irreplaceable role in molding of personal and esthetic value. But in the recent years, there are some problems in British and American Literature teaching. This paper analyzes some existing problems and teaching situation of British and American Literature, and discusses the main cause of these problems. Finally, this paper brings forward some countermeasures and some advice for the some existing problems of British and American Literature teaching.
\end{abstract}

\section{Introduction}

Literature is the crystals of human history and culture, which plays a unique role in inspiring man's mind and spirit. Outstanding literary work is the essence of human civilization, which is also created by writers with sharp insight and agile thinking. Whether rational enlightenment or emotional thinking, they can motivate the people' passion and impulsion [1]. In college teachers should not only teach our children the skills they will need in the future, but also the surviving spiritual supporting point of from classic literary work. British and American Literature, as an important of humanities, plays an irreplaceable role in molding of personal and esthetic value. The university, as the cradle to raise talents, should assume more responsibility in guiding students to care their spiritual home from literary reading and appreciation.

However, in recent years, British and American Literature teaching has been a more awkward position in English major teaching. Many college students had been interested in reading foreign classics and foreign literature speech in the past year. However, but the situation is dying away. Although teaching syllabus for English majors requires that British and American Literature course should be arranged at the beginning of the third year in college, the literature teaching course was neglected in actual teaching. There are many problems in the British and American Literature teaching [2]. These problems have already become educational concern. This paper will analyze the solving methods and the main cause of these problems.

\section{Some Reasons for Influencing British and American Literature Teaching}

Contemporary China is undergoing social transformation, the absent treatment of the British and American Literature are caused by many factors.

The Change of Social Values. In the past 20 years, the transition and reform of Chinese society have improved people' life and promoted greatly the development of economics and society. In addition, the further development of economics has profoundly altered people's thoughts. Existentialism and pragmatism have negative influences have been produced on college students. The life value of idealism has dropped out of mainstream ideology on college campus. Instead of this, the individualism and pragmatism play an important role on students' life values. Some students think that it is too far to reach in lifetime, and they pay attention to their own state of mind and the reality-based benefits. Many students only want to study practical knowledge, so that they can 
find a good job and enjoy comfortable life. In addition, impetuous wind has played an increasingly important role. Some students have become busier and busier, and they have been busy in looking for a part-time job and playing games. So they have no mind for reading the British and American Literature.

Humanities Education Imbalances. Basically, education maintains the two parts, humanities education and science education. The objective of science education is to teach the knowledge, so that people can grasp the natural laws and natural sciences and technical knowledge. The objective of humanities education is to pursue the ultimate concern of the individual and society. The humanity and science are the two wings of human development, they are indispensable. If science education represents the national and personal power, and the humanities education represents the national and personal soul. After the reform and opening, we will vigorously develop science and technology education. Chinese scientist and academician of the Chinese Academy of Sciences Yang Shuzi points out that our higher education puts a high value on material gain, and neglect the quality education [3]. Professor Zhang zhongzai also points out that our higher education attaches important to the Utilitarianism in current English education, and neglects the humanism [4]. Some colleges have put a high value on language as a tool principle, so some practical course had been emerged, such as business English, tourism English and legal English, etc.

The Lag of Teaching Method. Teachers often use cramming education teaching method to let students grasp literature knowledge in as short a time period as possible in British and American Literature course. Teachers teach knowledge from history background, author's life, writing style, work subject, art characteristic and character, etc. That has been the situation that teachers become tired, and students' thinking cannot keep up with the pace of teachers. The teaching mode which the teacher plays a role has not been adapted to our country's teaching. More and more students have lazier than ever before. Some students often feel that learning British and American Literature is stuffy. Then they will make a reason for giving up learning. Because British and American Literature course have many schools, it will bring greater pressure to the teachers. In addition, some teachers are so busy implementing science they overlook the opportunity to implement innovation and improvement of the teaching methods.

The Restriction of Teaching Material. The content and language of many literatures loses touch with social development. Many literary teaching materials pay more attention to classic book, and ignore the literary theory teaching. Over time, some abilities of students have been limited. They have some difficulty in understanding these literary works, and gradually lost interest in literature.

\section{Teaching Reform Strategy of British Literature and American Literature.}

In the new situation, how to implement the humanistic quality of education, shoulder historical mission and develop future educators has become an important topic of British and American literature educators.

Enhancing the Knowledge of British and American Literature Teaching Function. Good British and American Literature works have more human spirit, which is most important part of talent quality. So, British and American literature is often indispensable during the time of culturing good teachers. If students graduate from college are short of perfect personality and high moral, they will not become a good teacher. Teachers should focus on the humanistic quality of education and humanistic spirit edification. The rapid development of science and technology, the continuous updating of knowledge is leading us into an age of the knowledge update [5]. No college or university can educate its students by the time they graduate.

The role of British and American literature may not immediate effect, but it would have a far-teaching impact on the artistic abilities and imagination. The development of the artistic abilities will help students form own unique philosophy and thought, so as to train their personality and innovation.

Reading literary works can expose students to native and different language, which cannot only enlarge their vocabulary and enhance language sense, but also help students to understand western 
culture and experience traditional national culture. It is good for students to improve English application ability.

Rational Selection of British and American Literature Teaching Content. At present, in view of the decreasing class hour of British and American literature courses, teachers should focus on selecting teaching content of British and American literature, and carefully select meaningful literature sources. Teaching content should include at least the literature, works and criticism method. The former textbooks were either focus on the introduction to the literature or totally ignored the literature. Reading literature can help students understand the developing skeleton of British and American literature, so as to help the students understand literature works. Teachers should teach students to understand the most major literary school and representative writer. But because of the limit of teaching time, teachers only can summarize the literature content. In addition, the work selection should not too focus on classics, but rather focus on the readability of literary works [6]. The literary works should also not two difficult and dull, but makes the students understand works. This can help students to experience life and get close to life through reading the literary works. So, selecting the teaching content of British and American literature can inspire the reading interest of students, cultivate knowledge applying ability of students and improve the quality of students.

Implementing the reform of British and American Literature Teaching Method. The main role of Chinese traditional British and American literature teaching is the teacher who plays a center role on teaching model. This teaching model is dull, which suppress the subjectivity of students. In addition, another drawback of this teaching model cannot attract the reading interest of students, inspires the imagination and creativity of students with maximum. So it is urgent and important to implement the reform of teaching model. The reform of teaching model can be considered these points.

Developing Subjectivity of Students. In the course of teaching, teachers should respect the subject status of the student. Teachers should purposely encourage students to collect and teach some relative data before class, so as to discuss in class. In addition, teachers should also let students take part in classroom design personally, and encourage students to present their own views freely on writers, works and characteristic of works. In order to present own views and fully demonstrate yourselves, students will look up actively any information that they need. In class, teachers should use the heuristic teaching methods to teach students, so as to encourage students to take part in learning in the whole process of class.

Teachers can encourage students to state their views and express some views of the literary works. This method can help students cultivate their expression ability. When analyzing literary works, teachers should design some problems to let student think. Teachers can also inspire students to answer question actively and in the class. When students don't know the answer to something, teachers should guide them to think seriously. That way, students can implement automatic learning instead of the passive learning and take part in classroom teaching actively. In the teaching process of British and American literature teaching, the harmonious and relaxed atmosphere can not only exercise the language and logical thinking ability of students, but also improve learning efficiency and inspire students' potential.

Making Full Use of Modern Means of Education. With the development of science and technology and improvement of sponsoring college hardware conditions, it will become a tendency to make use of multimedia in British and American literature teaching. The resource on the network can significantly reduce the problems of poor teaching sources. Teachers can make some courseware of British and American literature teaching with the help of network sources. It can not only save time writing on aboard, but also attract student's attention.

For example, when teachers teach "Sense and Sensibility", they can firstly demonstrate the background information of the author. Secondly, teachers can analyze this work and comment it from spirit perspective and introduce Freudian psychoanalytic theory. Teachers can design some issues to admit students into class discussion. The discussions for the issues are helpful better to extend students' understanding of theory knowledge. After class, teachers can design some relative 
issues and require the students to work independently. This way can help students to develop independent thinking and problem solving ability.

Introducing the Comparative Literature into British and American literature teaching. British and American literature teaching should break traditional dimension limitation of time and space, and compare British and American literature with Chinese literature. The creation of literary works is not isolated behavior of the writers, but the crystallization of multicultural literature and multiple cultures.

Take Ezra Loomis Pound's In a Station of the Metro for example, the only two lines of poetry shows two group of corresponding images: one is Ghostlike faces of the Metro, the other is wet petals. This "faces" and "Metro" are two different and isolated images, and the poet brings two isolated images together, and become the compound of "faces" and "Metro". This method will cause rich association, endow limited and images with infinite and abstract content. Many ancient Chinese poets were also the same as Imagism. For example, the poet Liuzongyuan wrote a poem of Jiangxue. "Jiangxue" had some phrases, which shows some images. It makes readers feel they like being a part of them. These lines are totally immersed in the image, which shows the harmony between human and nature. Applying comparison of Chinese and western culture into teaching will help deepen students' understand of foreign and China's literature works, develop students' ability to appreciate literary works.

\section{Summary}

The higher teaching-training universities and colleges are the cradles of teachers and should clearly understand the importance of training teachers. How to meet the need of the future basic education, provide foreign language personnel of solid basic skills, high-quality for the society, it's a problem everybody must face. According to Professor Li Gongzhao, "Besides finding the reasons from society, environment, education and thinking, we should find the reasons from our own". From the perspective of British and American literature teaching, the teaching methods and teaching content have been on to go. Only continuously strengthen reform and study of British and American literature course can British and American literature course play an important role in humanistic quality education, better adapt to teaching reform and time reform.

\section{References}

[1] L. CAO. Eternal Utopian: Introductory Reader to Western Literature masterpieces. Beijing: Tsinghua University press, 2004.

[2] G. Z. Li. Situation and Thinking. Journal of Zhengzhou University (Social Sciences Edition), 5(2012): 11-15.

[3] Z. Z. Zhong. Functionalist and Humanism of Foreign Language Education, Foreign Language Teaching and Research, 2(2011): 25-28.

[4] A. H, Ma. Exploration on Teaching Method Optimization of English Literature. Foreign Language and Foreign Language Teaching, 2(2010): 36-39.

[5] S.Z. Zhang. Thinking on Teaching Reform of British and American literature for English Major, Continue Education Research, 2(2006): 130-133.

[6] R.Z. Lan. Language, Literature and College. Foreign Language and Foreign Language Teaching, 2(2010): 30-33. 